\title{
The cruelty man
}

Child welfare, the NSPCC and the State in Ireland,

1889-1956

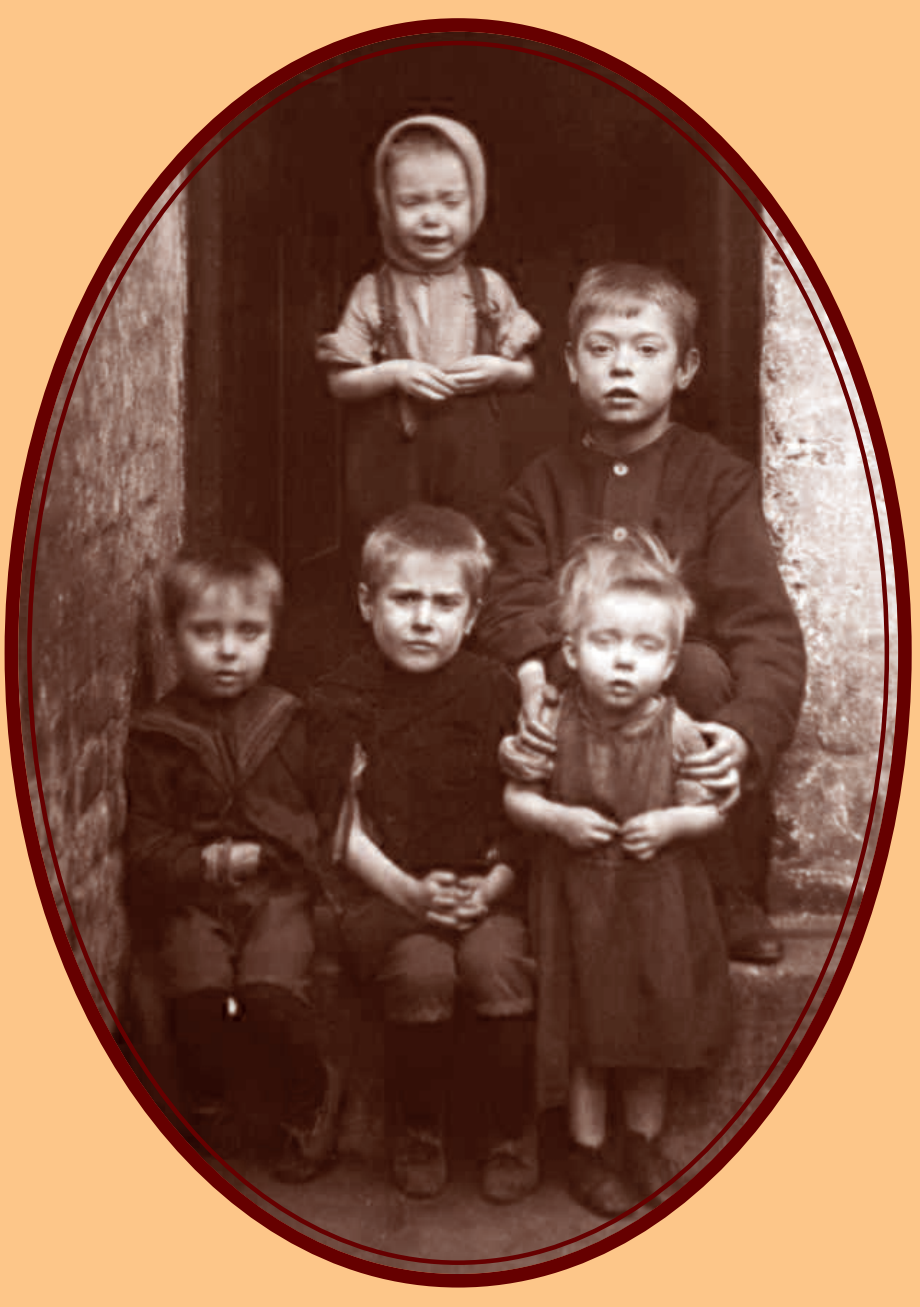

Sarah-Anne Buckley 
The cruelty man

MANCHESTER

1824

Manchester University Press 
Sarah-Anne Buckley - 9781526102706 Downloaded from manchesterhive.com at $04 / 26 / 2023$ ๑8: $08: 42 A M$ via free access 


\title{
The cruelty man \\ Child welfare, the NSPCC and the State in \\ Ireland, 1889-1956
}

\author{
Sarah-Anne Buckley
}

Manchester University Press

Manchester and New York

distributed in the United States exclusively by Palgrave Macmillan 
Copyright @C Sarah-Anne Buckley 2013

The right of Sarah-Anne Buckley to be identified as the author of this work has been asserted by her in accordance with the Copyright, Designs and Patents Act 1988.

Published by Manchester University Press

Oxford Road, Manchester M13 9NR, UK

and Room 400, 175 Fifth Avenue, New York, NY 10010, USA

www.manchesteruniversitypress.co.uk

Distributed in the United States exclusively by

Palgrave Macmillan, 175 Fifth Avenue, New York,

NY 10010, USA

Distributed in Canada exclusively by

UBC Press, University of British Columbia, 2029 West Mall,

Vancouver, BC, Canada V6T 1 Z2

British Library Cataloguing-in-Publication Data

A catalogue record for this book is available from the British Library

Library of Congress Cataloging-in-Publication Data applied for

ISBN 9780719087660 hardback

First published 2013

The publisher has no responsibility for the persistence or accuracy of URLs for any external or third-party internet websites referred to in this book, and does not guarantee that any content on such websites is, or will remain, accurate or appropriate.

Typeset by Special Edition Pre-Press Services 